\title{
«Mixed methods»-design i helseforskning
}

Et hovedargument for å mikse metodebruk er at det kan gi en bedre og dypere forståelse av tematikken man $\varnothing$ nsker å belyse, og dermed styrke tilliten til konklusjonene.

Janice Andersen

Genetisk veileder

Nasjonalt kompetansesenter for porfyrisykdommer, Laboratorium for klinisk biokjemi, Haukeland universitetssjukehus

Mixed methods Helsefag Kvalitativ Kvantitativ Metode

\section{Hovedbudskap}

Såkalte «mixed methods» er en stadig mer aktuell metodisk tilnærming. Hovedantakelsen er at man gjennom å kombinere både kvalitative og kvantitative data kan få en mer komplett forståelse av forskningsobjektet. Samtidig er det store utfordringer av både vitenskapsteoretisk, metodologisk og praktisk karakter.

Det er tre metodiske hovedretninger innen helsefaglig

forskning: kvalitativ, kvantitativ og mixed methods. 
Innen hver av disse hovedretningene er det en rekke ulike metoder og tradisjoner, men svært forenklet kan man si at kvalitativ forskning har til hensikt å unders $\varnothing$ ke og forstå mening som individer eller grupper tilskriver et fenomen eller menneskelig problem. Objektet for forskningen er individuell mening, kompleksitet og variasjon. Basert på en induktiv tilnærming, det vil si å oppdage mønstre og trekke slutninger fra det partikulære til det generelle, tolker forskeren dataenes mening. Eksempler på slik forskning er intervju, observasjon og tekstanalyse.

\section{三 «Mixed methods innebærer å samle og integrere både kvalitative og kvantitative data.»}

Kvantitativ forskning tester objektive teorier gjennom å unders $\varnothing \mathrm{ke}$ forholdet mellom variabler. Variablene måles ved hjelp av instrumenter og gir nummererte data som kan analyseres med statistiske prosedyrer. Eksempler kan være eksperimentelle design, tverrsnittstudier og kohorter.

Mixed methods, heretter forkortet MM, innebærer å samle og integrere både kvalitative og kvantitative data.

Hovedantakelsen bak denne tilnærmingen er at man gjennom å kombinere kvalitative og kvantitative data får en mer komplett forståelse av forskningstemaet enn ved å bruke hver enkelt tilnærming alene ( $\underline{1}, \underline{2}, \underline{3}, \underline{4})$.

\section{Historisk utvikling}

Forskere innen sosialantropologi og sosiologiske feltstudier mente på 1930-, 40- og 50-tallet at både kvalitative og kvantitative data var nyttige for å unders $\varnothing$ ke aktuelle forskningsspørsmål.

Campel og Fiske brukte begrepet «multippel operasjonalisering» og var i 1959 de første som viste eksplisitt hvordan man kunne bruke flere metoder som en del av en valideringsprosess for å kontrollere for at den forklarte variansen av et fenomen eller trekk ikke skyldtes metoden $i$ seg selv. Dette var altså mer en form for måle- og konstruktvalidering enn en egen metodologi.

Begrepet triangulering ble brukt av Webb og medarbeidere i 1966, men ble først definert av Denzin i 1978 som «kombinasjonen av metodologier i studiet av det samme fenomenet». Fire typer triangulering ble beskrevet: Man kunne bruke ulike typer data, ulike forskere, ulike teoretiske perspektiver for å tolke resultatene, eller flere metoder for å studere et forskningsspørsmål. 
Denzin skilte mellom å bruke enten flere kvalitative eller flere kvantitative metoder, såkalte «within-methods», og det å blande kvalitative og kvantitative metoder, det vil si «between-methods» ( $\underline{5})$.

\section{Definisjoner}

Å definere MM har vist seg å være utfordrende. MM innebærer mer enn bare å kombinere kvalitative og kvantitative data (1). Johnson og medarbeidere ( 5) har unders $\varnothing \mathrm{kt}$ hvordan ulike ledende forskere på feltet definerte MM. De fant at det var ulike synspunkter på blant annet hva det er som mikses, når i forskningsdesignet miksingen bør skje, og hensikten med å mikse forskningsmetoder.

Det var stor enighet om at det som mikses, bør være between-methods, altså å benytte både kvalitative og kvantitative data.

\section{三 «Det var uenighet om når i designet miksingen bør skje.»}

Det var likevel noen som mente at MM kan inkludere studier der man blander ulike typer kvalitative data eller ulike typer kvantitative data. Eksempler på slike within-methods er å bruke både deltakende observasjon og intervjuer i en kvalitativ studie, eller at man i en kvantitativ studie kombinerer såkalte objektive målinger, som biologiske parametere i en blodprøve, med et spørreskjema som fylles ut av deltaker.

Det var uenighet om når i designet miksingen bør skje. Et vanlig synspunkt er imidlertid at miksingen kan finne sted på alle stadier i forskningsprosessen. Dette innebærer at man kan ha relativt separate studier, men det må som et minimum være en integrering av de kvalitative og kvantitative komponentene i resultatdelen av studien for å kunne kalle den $\mathrm{MM}$ ( $\underline{5}$ ).

\section{Hvorfor mikse?}

Så hva er hensikten med å mikse i forskning? Et hovedargument er at miksing av metoder kan gi en bedre og dypere forståelse av tematikken man ønsker å belyse, og dermed styrke tilliten til konklusjonene ( $\underline{5}$ ). 
I artikkelen Toward a definition of mixed methods research

konkluderer forfatterne med at det er en viss konsensus om kjernen i MM, men at det også er en heterogenitet blant forskerne, noe de anser som naturlig, verdifullt og positivt for et nytt og voksende forskningsparadigme.

Det skilles mellom å mikse innad i en og samme studie og det å bruke ulike metoder i flere studier. De foreslår på bakgrunn av dette følgende generelle definisjon ( $\underline{5}$ :

«Mixed methods research is the type of research in which a researcher or team of researchers combines elements of qualitative and quantitative research approaches (that is, use of qualitative and quantitative viewpoints, data collection, analysis, inference techniques) for the broad purposes of breadth and depth of understanding and corroboration. A mixed methods study would involve mixing within a single study; a mixed method program would involve mixing within a program of research and the mixing might occur across a closely related set of studies.»

\section{Ulike måter å mikse på}

Det finnes generelt tre typer miksing av forskningsdata ( 6 ). Samlet bruk innebærer at man samler både kvalitative og kvantitative data, men at disse i liten grad brukes sammen. Et eksempel kan være en forskningsrapport der resultater fra ulike kvalitative og kvantitative artikler og studier samles for en felles konklusjon. Dette er et eksempel på at miksing skjer helt på slutten av et prosjekt med individuelle deler.

\section{三 «Integrering vil si at kvalitative og kvantitative komponenter assimileres.»}

Ved linking av resultater vil miksingen skje på resultatstadiet. Et eksempel kan være at man benytter en kvalitativ studie for å få informasjon om en intervensjon som man også har evaluert ved hjelp av et spørreskjema.

Integrering vil si at kvalitative og kvantitative komponenter assimileres. Resultater fra et intervju kan for eksempel omgjøres til tall som man kan analysere statistisk. Dette beskrives gjerne som «kvalitisering» og «kvantitisering» av data og er et eksempel på at man mikser allerede på datasamlings- og analysestadiet ( $\underline{6}$. 


\section{Mixed methods-design}

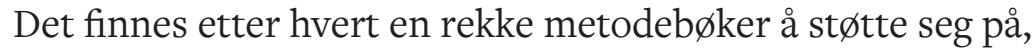
med ulike navn og definisjoner på de ulike designene. Likevel er det ett sett med grunnleggende forskningsdesign og analytiske prosesser som det er generell enighet om. Fordi disse er unike for MM og bidrar til å skille metoden fra kvalitativ og kvantitativ forskning, kan de kalles «signaturdesign» ( $\underline{7})$.

En vanlig forkortelse er at KVAL (engelsk QUAL) står for «kvalitativt» og KVAN (engelsk QUAN) står for «kvantitativt». Det som er skrevet med store bokstaver, regnes for å være det dominerende perspektivet i den aktuelle studien ( 8); se figur 1.

Tre grunnleggende forskningsdesign innen MM er sekvensielt forklarende design, sekvensielt utforskende design og triangulert design (figur 1) (7). Sekvensielt forklarende design vil si at man først analyserer data fra en kvantitativ del og deretter bruker disse for å kunne gå i mer detalj i en kvalitativ del av forskningen.

Figur 1: Tre grunnleggende forskningsdesign innen mixed methods

Sekvensielt forklarende design

KVAN

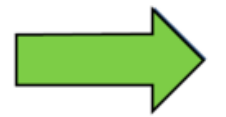

\section{kval}

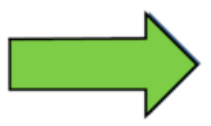

Tolkning basert på KVAN $\rightarrow$ kval

Sekvensielt eksplorerende design

KVAL

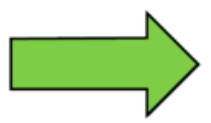

kvan

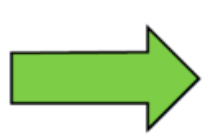

Tolkning basert på

KVAL $\rightarrow$ kvan

Triangulert design

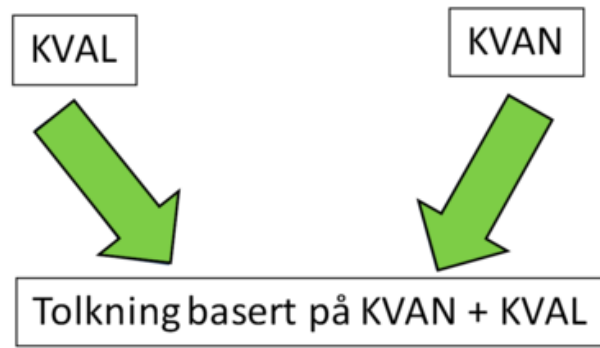


Sekvensielt utforskende design er det omvendte. Et eksempel er å bruke kvalitative data fra en intervjustudie til å utforme instrumenter eller til å velge ut instrumenter til videre forskning.

Et tredje hoveddesign er triangulert design, også kalt sammenløpende eller parallelle design. I slike forskningsdesign samler man typisk både kvalitative og kvantitative data omtrent samtidig og integrerer informasjonen i et overordnet resultat (9).

Selv om det er generell enighet om eksistensen av disse unike MM-designene, er det betraktelig uenighet rundt terminologi og definisjoner. Denne uenigheten øker når mer og mer komplekse typologier utvikles ( 7).

\section{Paradigmestrid}

Inkompatibilitetstesen, formulert av Howe i 1988 (10), sier at kvalitative og kvantitative forskningsparadigmer, inkludert deres assosierte metoder, verken kan eller bør mikses.

Denne tesen utgår fra den såkalte paradigmekrigen, som var filosofiske og metodologiske debatter mellom postpositivistiske, altså kvantitative, og konstruktivistiske, altså kvalitative, leire. Disse representerte ulike kunnskapssyn.

\section{三 «Ifølge inkompatibilitetstesen er disse verdenssynene så forskjellige at det ene utelukker det andre.»}

Slike kunnskapssyn, eller paradigmer, danner bakteppet for hvordan forskere observerer og samler inn data, og dermed også for hvordan spørsmål formuleres, og hvordan resultater av unders $\varnothing$ kelser tolkes.

Ifølge inkompatibilitetstesen er disse verdenssynene, og metodene utledet av dem, så forskjellige at det ene utelukker det andre. Man får da det som kan kalles «metodologisk purisme», med kvalitative og kvantitative «purister» på hver sin side i debatten. 


\section{Pragmatismen}

Forkjemperne for MM avviser en slik inkompatibilitetstese og hevder at å kombinere kvantitative og kvalitative metoder er både mulig og passende i mange forskningssituasjoner. I diskusjonen rundt hva som er eller bør være det paradigmatiske ståstedet for MM, mener noen at paradigmer er irrelevante (postpositivisme utelukker ikke kvalitative metoder, konstruktivisme utelukker ikke kvantitative metoder), mens andre hevder at det finnes flere paradigmer innen MM.

Pragmatismen er imidlertid det forskningsparadigmet som oftest er assosiert med MM. Med et slikt verdenssyn anser forskeren at det er forskningsspørsmålet som skal drive forskningen, og at spørsmålet er viktigere enn metoden.

Pragmatisme er, som navnet indikerer, en praktisk retning, hvor både induksjon og deduksjon er viktig. Både teorigenerering og teoriverifisering kan oppnås, og det oppfordres til metodisk pluralisme (1, $\underline{3}, \underline{7}, \underline{11})$.

\section{Produktive MM-design}

Ifølge tidsskriftet Journal of Mixed Methods Research ( 13) er artikkelen Methodological innovations in studying abortion in developing countries: a «narrative» quantitative survey in Madhay Pradesh, India (14) et eksempel på en god helsefaglig MM-studie.

En litteraturgjennomgang viste at tidligere studier av abort $\mathrm{i}$ utviklingsland stort sett tok for seg insidens og prevalens. Det som fantes av kvalitativ forskning, var gjort på kvinner som tok aborter på klinikker og institusjoner, og man manglet informasjon om både utbredelse og erfaringer fra fattige kvinner som gjennomfører abort i mer avsidesliggende områder.

\section{三 «Et MM-design kunne være velegnet for å bøte på svakheter ved tidligere forskning.»}

Litteraturgjennomgangen viste at et MM-design kunne være velegnet for å bøte på svakheter ved tidligere forskning. Studien benyttet et sekvensielt design, der man på bakgrunn av kvalitative data fra fokusgrupper og individuelle intervjuer utarbeidet et «hybrid-spørreskjema» med både lukkete svarkategorier og åpne spørsmål med en fortellende tilnærming for sensitive problemstillinger. 
Resultatene fra studien bidrar til mer fullstendig informasjon rundt både utbredelse av, erfaringer med og omstendigheter ved abort ( $\underline{13}, \underline{14})$.

I denne studien ble de kvalitative og kvantitative dataene integrert, ikke bare i utarbeidelsen av spørreskjemaet som brukes i den største delen av undersøkelsen, men også i det endelige resultatet. Det vil dermed si at de to komponentene integreres på både datainnsamlings-, analyse- og resultatstadiet av designet (13).

\section{Uproduktive MM-design}

Andre ganger viser imidlertid MM-prosjekter seg å være utfordrende. Et eksempel er det såkalte kneprosjektet (15). Kneprosjektet kan betegnes som uproduktivt, i og med at det ikke ble publisert noen samlete resultater.

I utgangspunktet $\varnothing$ nsket man å få besvart to spørsmål. Det første var kvantitativt: hvorfor personer med kneskader viste ulike funksjonelle ferdigheter etter rehabilitering. Det andre var kvalitativt: å utforske hvordan pasientene så på rehabiliteringsprogrammet, og hvordan de praktiserte $\varnothing$ velsene i programmet.

At dette skulle bli en MM-studie, var motivert av de to forskningssp $\varnothing$ rsmålene, men også av et ønske om å utnytte potensialet som lå i at solid kompetanse på både fenomenologisk og fysiologisk forskning fantes ved samme institusjon.

I tillegg til å få mer kunnskap om rehabiliteringsprogrammet ønsket man også å bygge opp en kapasitet for interdisiplinært samarbeid på lengre sikt. Det var derfor fra starten av et $\varnothing$ nske om å gjøre «forskning på forskningen», og en kvalitativ forsker utenom gruppen deltok som observat $\varnothing$ r.

\section{Punsjefeil}

Det viste seg at det ble store utfordringer knyttet til dataintegrering og samarbeid. Hovedproblemet i kneprosjektet var at man ikke klarte å integrere de ulike datasettene og komme videre med prosjektet ( $\underline{15}$ ).

De som ble kategorisert som «mestrere» i de kvantitative målingene, viste seg å være det motsatte i de kvalitative fortellingene. Dette ble vurdert som kategoriseringsfeil eller punsjefeil og ble ikke sett på som en ressurs, men som et problem. 


\section{$\equiv$ «Integrering av data krever ikke nødvendigvis konsistente resultater og funn.»}

Det er nærliggende å anta at hvis forskerne ikke hadde oppfattet motsetningene mellom de kvalitative og kvantitative funnene som et problem, kunne prosjektet kanskje fătt frem genuin og verdifull kunnskap som var mer enn summen av det kvalitative og kvantitative til sammen.

Et viktig poeng ved MM er at integrering av data ikke nødvendigvis krever konsistente resultater og funn. Snarere tvert imot bør inkonsistens ses på som en ressurs (16). Det ble aldri gjort noen konklusjoner på dette. Så vidt man kjenner til, er ingen samlete resultater publisert, og prosjektet ble slik sett ikke fullført ( $\underline{15})$.

\section{Utfordringer}

Ifølge Journal of Mixed Methods Research er et hovedproblem med de empiriske artiklene som refuseres av dem, at de kun benytter enten bare kvalitative eller bare kvantitative komponenter, noe som tyder på en misforståelse av hva MMforskning er. Andre mangler kan være en lite tilfredsstillende integrering av metode, analyse eller rapportering av data ( $\underline{13}$ ).

Genuin integrering vil det være der forskerne evner å analysere, tolke og skrive sammen sin forskning, slik at de kvalitative og kvantitative delene gjensidig belyser hverandre. Et viktig poeng ved MM er at sluttproduktet skal bidra med noe mer enn summen av de individuelle kvalitative og kvantitative delene.

Bryman (16) hevder at problemer med dataintegrering i liten grad er et tema som diskuteres, men at det som et minimum kan tenkes at man i så fall ikke får fullt utbytte av dataene man har samlet. Det kan skyldes at dette ikke blir vektlagt av forskerne i utgangspunktet, eller at det er praktiske vanskeligheter som svekker deres vilje og evne til å integrere funnene.

\section{$\equiv$ ¿Sluttproduktet skal bidra med noe mer enn summen av de individuelle kvalitative og kvantitative delene.»}


Det virker som om det er selve integreringen av de kvalitative og kvantitative komponentene på analyse- og resultatstadiet som er akilleshælen. En utfordring kan være at ulike publikum vurderer de ulike funnene forskjellig. Hvis man opplever at sluttbrukerne av et forskningsprosjekt verdsetter den ene komponenten over den andre, kan det føre til at denne delen av funnene får større plass.

Også publisering kan hindre integrering fordi noen tidsskrift foretrekker den ene typen funn fremfor den andre.

\section{Metodepreferanser}

Videre vil noen vektlegge ett sett av resultater fremfor et annet, fordi det er disse resultatene man har mest tiltro til. Det kan skyldes metodologiske preferanser, eller at man er mer fortrolig med den ene av de to tilnærmingene.

En måte å overkomme dette på kan være å sette sammen et team av forskere med ulik kompetanse. Men et slikt samarbeid kan også være utfordrende, på grunn av for eksempel ulike ferdigheter eller problemer med deling av roller og ansvar.

I kneprosjektet klarte ikke forskerne - som var erfarne og svært kompetente på sine fagfelt - å komme til enighet og fullføre prosjektet. Man kan undre seg over hvorfor dyktige og kompetente forskere ikke klarte å overkomme disse barrierene, men en årsak kan ha vært at de ulike miljøene hadde stor prestisje innen sine respektive felt: De hadde mye å tape og ingenting å vinne på å stille spørsmål ved egen metodologi og resultater ( $\underline{15})$.

\section{Hensiktsmessighet}

MM har sprunget ut av et $\varnothing$ nske om å kunne bruke de metodene som man anser som mest hensiktsmessige for å besvare det eller de aktuelle forskningsspørsmålene. Dette har bunnet i et ønske om å komme videre fra dikotomien kvalitativt versus kvantitativt; MM anerkjenner begge tilnærmingene som viktige og nyttige.

Denne gjennomgangen har vist at det er mange utfordringer ved å velge et MM-design. Forskeren må ha kompetanse ikke bare på både kvalitativ og kvantitativ forskning, man må også delvis sette seg inn i en tredje metode, det som har blitt betegnet som en tredje metodologi (1). 
Innen MM-forskningsfeltet finnes komplekse

forskningsdesign og en rekke ulike navn og typologier. Dette

kan være mye å forholde seg til og er noe man bør tenke godt gjennom før man begir seg ut i et MM-prosjekt, spesielt som ny og uerfaren forsker.

\section{Forskningskulturer}

Gjennom å arbeide i team kan man benytte seg av ulike forskningskompetanser og derved løsne litt på kravet om kompetanse på flere forskningsfelt. Men å delta i forskningsteam kan også innebære utfordringer knyttet til individuelle personligheter, særegenheter og kommunikasjon.

Selv om dette er utfordringer som kan oppstå uavhengig av metodologi, kan samarbeid på tvers av forskningskulturer ha sine egne utfordringer. Som et minimum må alle deltakerne være såkalt metodologisk tospråklige ( 17).

\section{三 «Som et minimum må alle deltakerne være såkalt metodologisk tospråklige.»}

MM har imidlertid vist seg spesielt hensiktsmessig på enkelte områder. Et eksempel er der kvalitative data ligger til grunn for utarbeidelsen av måleinstrumenter og spørreskjema. MM er også økende innen utvikling og evaluering av helsefaglige intervensjoner ( 12$)$.

Tilnærmingen har også blitt benyttet hypotesegenererende. Med bruk av et sekvensielt design kan man benytte kvalitative data for å generere en hypotese som man senere kan teste med kvantitative metoder. Vice versa kan man også bruke kvalitative studier for å utdype og forklare funn fra en kvantitativ studie $(\underline{1}, \underline{16})$.

\section{Konklusjon}

Denne gjennomgangen av MM-design i helseforskning viser at feltet er komplekst og sprikende. Samtidig er helseforskning et område som spenner vidt, og som innebærer at verden ikke bare kan forstås i et postpositivistisk eller konstruktivistisk perspektiv alene.

Det å benytte både kvalitative og kvantitative metoder i prosjekter synes å være stadig mer vanlig - og i mindre grad problematisert enn tidligere. Ved å oppfordre til slik metodologisk tospråklighet kan man øke samarbeid på tvers av fagfelt og forskningstradisjoner. 
Et enkeltstående helsefaglig forskningsprosjekt, det være seg kvalitativt, kvantitativt eller mikset, kan ikke alene gi et fullstendig bilde av et fenomen, men kan være et skritt nærmere en sannhet som er tentativ, kompleks og uuttømmelig.

Ved å innta en «mikset posisjon», med ulike perspektiver på kunnskap, metodisk pluralisme og en eklektisk tilnærming til helseforskning, kan man få en bredere og mer fullstendig forståelse av det temaet som unders $\varnothing$ kes. Samtidig er det til sjuende og sist problemstillingen som bestemmer om MM er den rette tilnærmingen.

\section{Referanser}

1. Polit DF, Beck CT. Nursing research: generating and assessing evidence for nursing practice. 9. utg. Philadelphia: Wolters Kluwer Health; 2012.

2. Creswell JW. Research design: qualitative, quantitative, and mixed methods approaches. 4. utg. / International student ed. Los Angeles: SAGE; 2014.

3. Johnson RB, Onwuegbuzie AJ. Mixed methods research: A research paradigm whose time has come. Educational Researcher. 2004;33(7):14-26.

4. Curry LA, Nembhard IM, Bradley EH. Qualitative and mixed methods provide unique contributions to outcomes research. Circulation. 2009;119(10):1442-52.

5. Johnson RB, Onwuegbuzie AJ, Turner LA. Toward a definition of mixed methods research. Journal of Mixed Methods Research. 2007;1(2):112-33.

6. Sandelowski M. Unmixing mixed-methods research. Res Nurs Health. 2014;37(1):3-8.

7. Tashakkori A, Teddlie C. SAGE handbook of mixed methods in social \& behavioral research. Thousand Oaks: SAGE; 2010.

8. Morse J, Niehaus L. Mixed method design: principles and procedures. Walnut Creek: Left Coast press; 2009.

9. Creswell JW, Plano Clark VL. Designing and conducting mixed methods research. Thousand Oaks: SAGE; 2011. 
10. Howe KR. Against the quantitative-qualitative incompatibility thesis or dogmas die hard. Educational Researcher. 1988;17(8):10-16.

11. Wiggins BJ. Confronting the dilemma of mixed methods. Journal of Theoretical and Philosophical Psychology. 2011;31(1):44.

12. O'Cathain A, Murphy E, Nicholl J. Why, and how, mixed methods research is undertaken in health services research in England: a mixed methods study. BMC Health Services Research. 2007;7:85.

13. Mertens DM. Publishing mixed methods research. Journal of Mixed Methods Research. 2011;5(1):3-6.

14. Edmeades J, Nyblade L, Malhotra A, MacQuarrie K, Parasuraman S, Walia S. Methodological innovation in studying abortion in developing countries: a «narrative» quantitative survey in Madhya Pradesh, India. Journal of Mixed Methods Research. 2010;4(3):176-98.

15. Lunde A, Heggen K, Strand R. Knowledge and power: exploring unproductive interplay between quantitative and qualitative researchers. Journal of Mixed Methods Research. 2013;7(2):197-210.

16. Bryman A. Barriers to integrating quantitative and qualitative research. Journal of Mixed Methods Research. 2007;1(1):8-22.

17. O'Cathain A, Murphy E, Nicholl J. Multidisciplinary, interdisciplinary, or dysfunctional? Team working in mixedmethods research. Qual Health Res. 2008;18(11):1574-85. 